\title{
Hepatitis B e Antigen Seroconversion Is Related with the Function of Dendritic Cells in Chronic Hepatitis B Virus Infection
}

\author{
Chunjing Lin, ${ }^{1}$ Hai Zou, ${ }^{2}$ and Shumin Wang ${ }^{2}$ \\ ${ }^{1}$ Department of Gastroenterology, First Affiliated Hospital of Wenzhou Medical University, Wenzhou, Zhejiang 325000, China \\ ${ }^{2}$ Department of Hepatology, Sixth Affiliated Hospital of Wenzhou Medical University, Lishui, Zhejiang 323000, China \\ Correspondence should be addressed to Shumin Wang; wsm18957091502@126.com
}

Received 6 July 2014; Accepted 13 November 2014; Published 9 December 2014

Academic Editor: Paolo Gionchetti

Copyright (C) 2014 Chunjing Lin et al. This is an open access article distributed under the Creative Commons Attribution License, which permits unrestricted use, distribution, and reproduction in any medium, provided the original work is properly cited.

\begin{abstract}
Aim. To investigate the relationship between hepatitis B e antigen seroconversion and the function of dendritic cells (DC) in patients with hepatitis B virus. Methods. The peripheral blood mononuclear cells (PBMC) from 21 chronic HBV patients in immune tolerance state, 23 patients in inactive HBsAg carrier state, and 10 healthy HBV-naive blood donors were incubated and induced into DC in presence of granulocyte-macrophage colony stimulating factor (GM-CSF) and interleukin-4 (IL-4), respectively. The expressions of surface markers on DC were detected by flow cytometry, and the stimulatory capacity of DC in allogenic mixed leukocyte reaction (MLR) was tested by CCK-8, and the level of cytokines released by DC was analyzed by enzyme-linked immunosorbent assay (ELISA). Results. DC from patients in immune tolerance showed a remarkably lower surface expression of CD80, CD86, and HLA-DR and exhibited an impaired stimulatory capacity in MLR and reduced secretion of IL-12, as compared to the patients in inactive HBsAg carrier state. There was no significant difference between the indicators from the patients in inactive HBsAg carrier state and healthy subjects. There was a significant difference of HBV DNA level between immune tolerance and inactive HBsAg carrier group $(P<0.01)$ and a negative correlation between HBV DNA level and the expressions of dendritic cells in both groups, respectively $(P=0.01)$. Conclusion. DC from patients in inactive HBsAg carrier state shows stronger function in comparison with patients in immune tolerance, the expressions of dendritic cells correlate with HBV DNA level, and the function stage of DC may play an important role in HBeAg seroconversion.
\end{abstract}

\section{Background}

According to statistics, chronic infection with hepatitis B virus (HBV), which poses serious risks to human, currently affects about 350 million people [1-3], and China alone has over 120 million people. Hepatitis B infection is a leading cause of chronic hepatitis, cirrhosis, and hepatocellular carcinoma [4], accounting for 1 million deaths annually. The natural course of chronic HBV infection can be divided into four phases: immune tolerance, immune clearance, low or nonreplication, and reactivation $[5,6]$. Inphase 1 patients are $\mathrm{HBeAg}$ positive with high $\mathrm{HBV}$ replication but minimal liver disease, and phase 3 is the inactive phase during which $\mathrm{HBeAg}$ is absent, viral concentrations are low, and there is minimal inflammatory activity in the liver. Although liver disease activities are low in phase $1,25 \%$ of them tend to have liver disease progression through frequency, extent, and severity of hepatitis flares or acute exacerbations in the second immune clearance; in general, early termination of immune tolerance and subsequent $\mathrm{HBeAg}$ seroconversion usually confer a favorable outcome, whereas delayed $\mathrm{HBeAg}$ seroconversion may accelerate the progression of liver disease.

In the pathogenesis of persistent HBV infection, both the virus and the immune response of the host play a major role. Recently, accumulating reports have shown that the number and the function of dendritic cells are impaired to a certain extent in patients infected with hepatitis $B$ virus $[7,8]$. An impaired function of DC may be suggested to account for HBV antigen-presenting and T cells stimulation defect, which may be the cause of chronic hepatitis $B$ virus infection. 
TABLE 1: Clinical characteristics of patients and normal controls (mean \pm SD).

\begin{tabular}{lccc}
\hline Parameters & $\begin{array}{c}\text { IT patients } \\
\left.\text { (HBV-DNA }>10^{4} \text { copies } / \mathrm{mL}\right)\end{array}$ & $\begin{array}{c}\text { ISC patients } \\
\text { (HBV-DNA }<10^{4} \text { copies/mL) }\end{array}$ & $\begin{array}{c}\text { Normal controls } \\
n\end{array}$ \\
\hline$n$ & 21 & 23 & 10 \\
Age (years) & $30.36 \pm 7.79$ & $33.15 \pm 6.91$ & $29.10 \pm 4.33$ \\
Sex (male/female) & $10 / 1$ & $11 / 2$ & $6 / 4$ \\
ALT (IU/L) & $36.45 \pm 16.94$ & $29.62 \pm 13.91$ & $30.10 \pm 11.82$ \\
AST (IU/L) & $30.64 \pm 11.84$ & $29.23 \pm 10.03$ & $26.90 \pm 12.13$ \\
HBV-DNA (lg copies/mL) & $6.42 \pm 1.07^{*}$ & $3.32 \pm 3.93$ & - \\
Genotype (type B/C) & $4 / 17$ & $9 / 14$ & - \\
\hline
\end{tabular}

Note: ${ }^{*} P<0.01$ versus ISC patients.

Thus, in this study, we investigated the phenotype and function of dendritic cells generated from peripheral blood mononuclear cells (PBMCs) of patients in immune tolerance and low or nonreplication to determine whether there is any difference between them. We hope that these data will be useful in explaining the difference of immune status and level of virus between the patients from two phases.

\section{Objectives}

The objectives are to detect the functional state of dendritic cells from different patients and relate the function and the state of HBV replication.

\section{Study Design}

3.1. Subjects. In total, 44 patients with chronic $\mathrm{HBV}$ infection were enrolled from the First Affiliated Hospital of Wenzhou Medical College. All the cases were identified according to chronic hepatitis B diagnosis standard (Conference in Xi'an, China, September 2000); patients were positive for hepatitis B surface antigen for at least 6 months; we excluded the patients with other viral hepatitis infections, and anti-HIV were negative. No patient studied had received antiviral treatment before or had any complication such as hepatic cirrhosis and hepatocellular carcinoma (HCC). The 44 patients were divided into two groups: 21 patients were $\mathrm{HBeAg}$ positive in immune tolerance (IT) with high serum levels of HBV-DNA, also seropositivity for $\mathrm{HBs} \mathrm{Ag}$ and anti-HBcAbs and normal alanine aminotransferase (ALT) levels; the level of ALT in serum was measured by autoanalyzer (HITACHI 7600110ISE); the cutoff for the upper limit of normal (ULN) was ALT $50 \mathrm{U} / \mathrm{L} ; 23$ patients were anti-HBeAb positive in inactive HBsAg carrier state (ISC) with undetectable or low levels of $\mathrm{HBV}-\mathrm{DNA}$ and also HBsAg and anti-HBcAb positivity and normal ALT levels. All the patients in group IT and group ISC were analysed for the HBV genotype. The baseline clinical data were shown in Table 1. As controls, 10 healthy HBV-naive blood donors (NC) were assessed. The study protocol was approved by the ethics committee of the author's unit, and written informed consent was obtained from all individuals.

3.2. Dendritic Cell Isolation and Culture. Monocyte-derived DCs (MoDCs) were prepared from peripheral blood mononuclear cells (PBMCs) mainly according to previously established protocols $[9,10]$. PBMCs were isolated from freshly drawn heparinized whole blood by Ficoll-Hypaque density gradient centrifugation, washed two times, and resuspended at $2 \times 10^{6} / \mathrm{mL}$ in RPMI 1640 (RPMI 1640 medium was purchased from GIBCO BRL, Gaithersburg, $\mathrm{MD}$, USA). After $3 \mathrm{~h}$ incubation at $37^{\circ} \mathrm{C}$ in $5 \% \mathrm{CO}_{2}$ in 6-well plates, supernatant was discarded and adherent cells were incubated in RPMI 1640 plus 10\% fetal bovine serum overnight. The nonadherent cells were gently removed, RPMI 1640 with $10 \%$ fetal bovine serum supplemented with $100 \mathrm{ng} / \mathrm{mL}$ of rhGM-CSF (Peprotech, England). And $50 \mathrm{ng} / \mathrm{mL}$ of rhIL-4 (Peprotech, England) was added to the wells. Half of the medium was refreshed and cytokine was added at the middle concentration every 2 days. On the 7 th day of incubation, $25 \mathrm{ng} / \mathrm{mL}$ of $\operatorname{rhTNF}-\alpha$ (Peprotech, England) was added to the medium, and then the cells were collected on the 9 th day.

3.3. Morphology of Dendritic Cells. The morphology of dendritic cells was monitored by light microscope.

3.4. Flow Cytometry of Surface Markers. On day 9, dendritic cells were harvested and stained with conjugated monoclonal mouse-anti-human antibodies, FITC-anti-CD80, PEanti-CD86, and PE-anti-HLA-DR (all purchased from Ebioscience, San Diego, USA), for $20 \mathrm{~min}$ at room temperature in darkness. Isotype-matched antibodies were used as controls. After washing once with PBS, dendritic cells were fixed in 1\% paraformaldehyde and analyzed by flow cytometry.

3.5. T Cell Stimulation. After being treated with $25 \mu \mathrm{g} / \mathrm{mL}$ of mitomycin at $37^{\circ} \mathrm{C}$ for $30 \mathrm{~min}$, dendritic cells were plated at concentrations of $2 \times 10^{4}, 1 \times 10^{4}$, and $5 \times 10^{3}$ cells per well separately, then mixed, and incubated with nonadherent PBMC from the same healthy person at concentrations of $1 \times 10^{5}$ cells per well in triplicate. The total volume was adjusted to $200 \mu \mathrm{L} /$ well, and the cells were incubated in RPMI 1640 with $10 \% \mathrm{FBS}$ for additional $96 \mathrm{~h}$ at $37^{\circ} \mathrm{C}$ in $5 \% \mathrm{CO}_{2}$, then $20 \mu \mathrm{L} /$ well tetrazolium salt (CCK-8) (purchased from Tongren, Japan) was added to the medium for $4 \mathrm{~h}$ before the end of culture, while T lymphocyte group (without dendritic cells incubated together) and only RPMI 1640 medium 


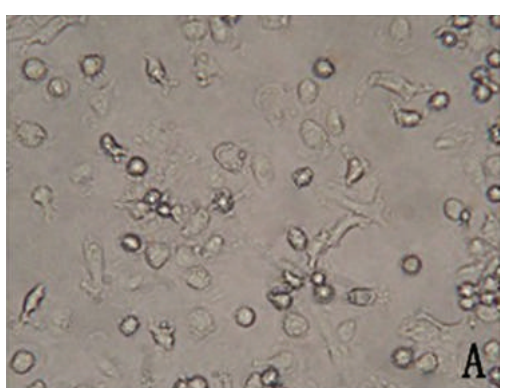

(a)

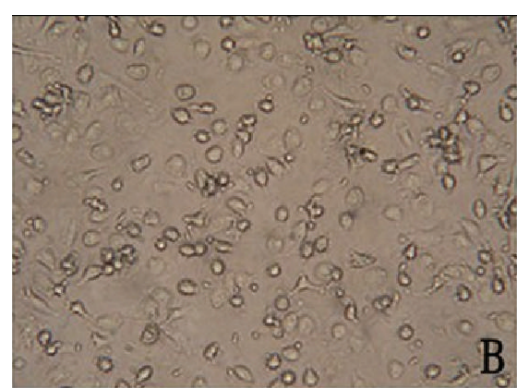

(b)

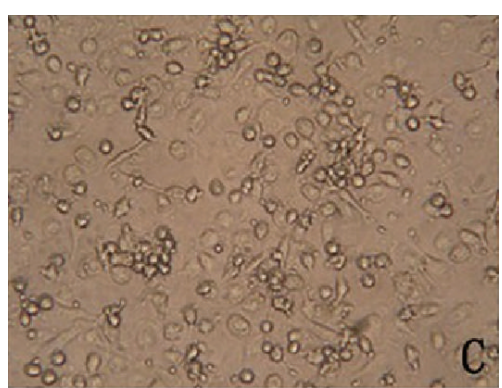

(c)

FIGURE 1: Morphological characteristics of dendritic cells in light microscope that were cultured for 7 days from two kinds of chronic HBV carriers and healthy controls $\times 200$. (a) Dendritic cells cultured from patients in immune tolerance; (b) dendritic cells cultured from patients in inactive HBsAg carrier state; (c) dendritic cells cultured from normal controls.

TABLE 2: Detection of dendritic cells' phenotypes in patients and normal controls (\%, mean \pm SD).

\begin{tabular}{lcccc}
\hline Group & Case & CD80 (\%) & CD86 (\%) & HLA-DR (\%) \\
\hline IT patients & 21 & $11.98 \pm 6.69^{* \#}$ & $90.03 \pm 3.01^{* \#}$ & $38.40 \pm 8.52^{* \#}$ \\
ISC patients & 23 & $34.83 \pm 9.62$ & $95.99 \pm 4.59$ & $54.38 \pm 12.45$ \\
Normal controls & 10 & $37.62 \pm 9.88$ & $96.15 \pm 3.33$ & $58.32 \pm 7.68$ \\
\hline
\end{tabular}

Note: ${ }^{*} P<0.01$ versus ISC patients and ${ }^{\#} P<0.01$ versus normal controls.

group were, respectively, established as negative control group and background group. Absorbance $(A)$ was measured by ELX800G (Biotech, USA) at a detection wavelength of $450 \mathrm{~nm}$ and a reference wavelength of $630 \mathrm{~nm}$. The results were expressed as stimulation index (SI) calculated by the following formula: stimulation index $=$ (values of the sample the background values)/(values of the negative control - the background values).

3.6. Cytokine Secretion by Dendritic Cell. Supernatants from mixed lymphocyte reaction (MLR) were collected on day 4 and IL-12p70 was detected using an enzyme-linked immunosorbent assay (ELISA), which was purchased from R\&D Systems (Minneapolis, MN, USA) and following the manufacturer's instruction.

3.7. Data Analysis. Data were expressed as mean \pm SD. All data were analyzed utilizing SPSS-XII software. Parameters collected with homogeneity of variance between groups were determined by least significant difference test (LSD), while data with heterogeneity of variance were determined by Dennett T3 test. Correlations between HBV DNA level and the expressions of dendritic cells were evaluated using Spearman's correlation coefficient.

\section{Results}

4.1. Morphological Characteristics of Dendritic Cells. On the third day, many cells grew branched projections and small adherent aggregates could be observed. On the 7 th day, more and more cells were induced and began to suspend. In contrast to another two groups, dendritic cells of patients in immune tolerance have more dead or apoptosis cells with particles in cytoplasm, which are shown in Figure 1.
4.2. Phenotype of Dendritic Cells. On day 9 of culture, phenotypic analysis showed that expression levels of CD80, CD86, and HLA-DR were lower in patients in immune tolerance than that in another two groups. Isolated dendritic cells from patients in inactive HBsAg carrier state exhibited similar expression of surface molecules as dendritic cells from healthy controls. The results were shown in Table 2 and Figure 2.

4.3. Allogeneic $T$ Cell Proliferation of Dendritic Cells. In allergenic mixed leukocyte reaction, the level of T cell proliferation induced by dendritic cells increased in ratio between DC and T cell-dependent manner. Dendritic cells from ISC patients had a stronger stimulatory capacity than that from IT patients in Figure 3. There was a significant difference between them, especially when $\mathrm{DC}$ and $\mathrm{T}$ cell were at a ratio of $1: 5$ and $1: 10$. The experiment did not reveal significant differences between DC from ISC patients and healthy control in $\mathrm{T}$ cell proliferation.

4.4. Cytokine Secretion by Dendritic Cells. The levels of IL$12 \mathrm{p} 70$ were $28.11 \pm 4.29 \mathrm{pg} / \mathrm{mL}$ in IT patients, $34.05 \pm$ $6.11 \mathrm{pg} / \mathrm{mL}$ in ISC patients, and $35.46 \pm 4.93 \mathrm{pg} / \mathrm{mL}$ in healthy controls. The results showed that IL-12p70 was reduced quantitatively in dendritic cells cultured from IT patients compared with ISC patients or healthy controls. However, there were no statistically significant differences between dendritic cells from patients in inactive HBsAg carrier state or healthy people in the secretion of IL-12p70.

4.5. HBV DNA Level and Genotype. There was a significant difference of HBV DNA level between immune tolerance and inactive HBsAg carrier group $(P<0.01)$ and a negative 

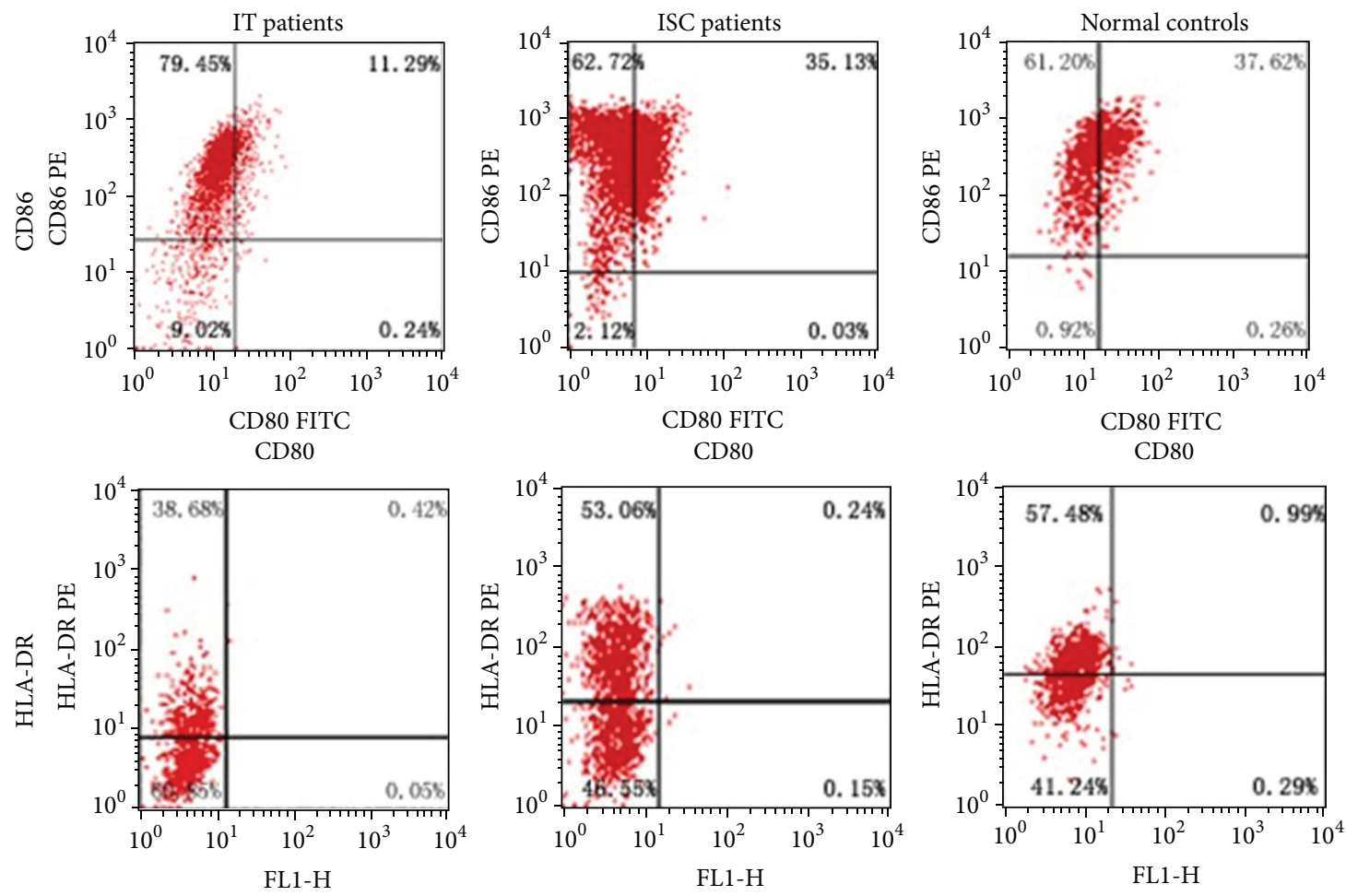

FIGURE 2: Expression of surface markers on dendritic cells cultured for 9 days.

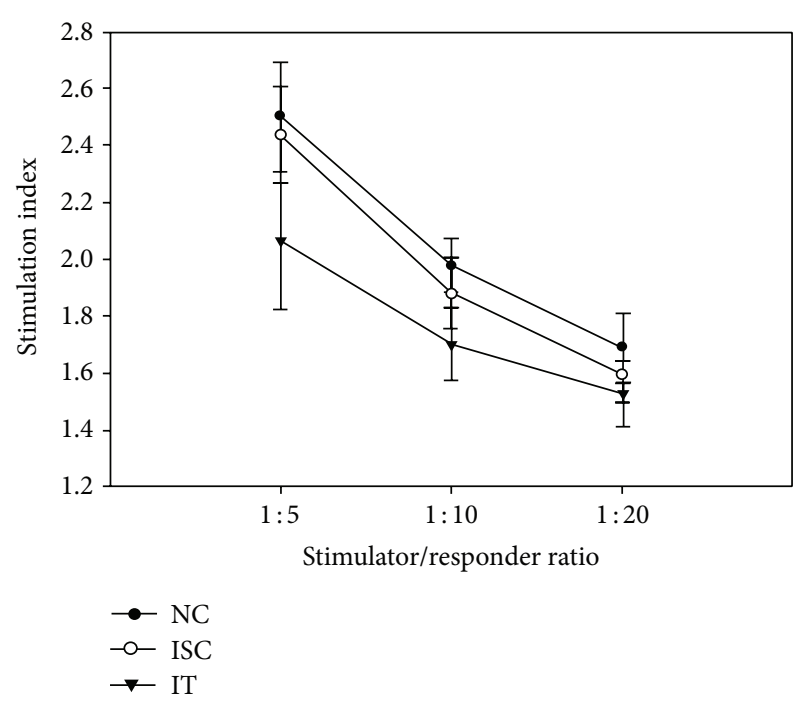

FIGURE 3: Effect of dendritic cells' stimulation on proliferation of T lymphocytes in mixed lymphocytes reaction.

correlation between HBV DNA level and the expressions of dendritic cells in both groups, respectively $(P=0.01)$. All the patients were of genotype $B$ or genotype $C$ in these two groups. The percentage of genotype $\mathrm{C}$ was higher than genotype B in group IT and group ISC, respectively. Furthermore, the percentage of genotype $\mathrm{C}$ in group IT was higher than that in group ISC.

\section{Discussion}

The mechanism of how viral infections evade the immune response and lead to chronic infection has become a research hot spot. It is believed that the cytotoxic T lymphocyte (CTL) response plays a major role in controlling $\mathrm{HBV}$ infection [11]. Patients with acute viral hepatitis, who successfully cleared the virus, mounted a large number of $\mathrm{HBV}$-specific CTL response. On the contrary, this response is absent or extremely weak in chronically infected patients who do not clear the virus. Thus, viral persistence or chronicity is associated with an inadequate CTL response $[12,13]$.

Dendritic cells are considered as the most powerful antigen-presenting cells (APCs) playing a strategic role in initiating and modulating the immune response [14]. DCs are uniquely well equipped in antigen-capturing, processing, and presenting function and act as key players in initiating $\mathrm{T}$ lymphocyte activation against viral agents $[15,16]$. Beckebaum et al. [17] proposed that $\mathrm{HBV}$ infection compromised the antigen-presenting function of DC with concomitant impairment of T helper cell type 1 responses.

In this present study, by the means of GM-CSF and IL-4, DC isolated from IT patients showed decreased expression of CD80, CD86, and HLA-DR and lower allostimulatory capacity when DC and T cell were at a ratio of $1: 5$ and $1: 10$ compared with ISC patients. However, there was no significant difference between them when $\mathrm{DC}$ and $\mathrm{T}$ cell were at a ratio of $1: 20$. Perhaps the main reason for that is that the number of DCs is too small, leading to no obvious difference in lymphocyte proliferation. 
At least, two signals are necessary to activate a naive lymphocyte before it can recognize and target HBV antigen. Binding of the antigen-MHC complex and TCR on naive T lymphocyte represents the first activation signal; costimulatory signal provided by ligation of CD28 by B7 molecules on the naive $\mathrm{T}$ cell represents the second signal. Activated DCs have an ability to process antigens and express high levels of costimulatory molecules; thus they can provide both signals needed for $\mathrm{T}$ cell activation. In our study, the low expression of costimulatory molecules and reduced allostimulation by IT patients DC would indicate failure of antigen presentation, specially $\mathrm{HBeAg}$ presentation and $\mathrm{T}$ cell stimulation, inducing lack of HBV-specific immune response, which may play an important role in the difference of immune response between IT patients and ISC patients. By testing the effect of passive immunization with anti-HBe immunoglobulin free of antibody to hepatitis B surface antigen on experimental HBV infection in the chimpanzee model, Stephan et al. [18] suggested that anti-HBe might have biological activity in the modulation of $\mathrm{HBV}$ replication. Therefore, the reason for obvious differences in HBV replication between IT and ISC patients may be due to the lack of immune response to $\mathrm{HBeAg}$ caused by dysfunction of DC.

The key cytokines provided by DC are considered the third pathway to initiate an adaptive immune response. IL12 is a main effector in the third pathway to induce helper T lymphocyte (Th) response towards Thl cell differentiation. It is also involved in the generation of cytotoxic $\mathrm{T}$ lymphocyte (CTL) and activation of cytotoxicity in CD8+ $\mathrm{T}$ cells, especially potentiating gamma interferon (IFN- $\gamma$ ) production by $\mathrm{T}$ lymphocytes [19]. Our experimental results showed a reduced secretion of IL-12 by DC in IT patients which induced Th1/Th2 imbalance. This discrepancy may lie in $\mathrm{HBV}$ persistent replication.

After $\mathrm{HBeAg}$ seroconversion, some patients reach the fourth phase as $\mathrm{HBeAg-negative} \mathrm{chronic} \mathrm{hepatitis} \mathrm{B} \mathrm{char-}$ acterized by negative $\mathrm{HBeAg}$, positive anti-HBe, detectable HBV-DNA $\left(10^{4}-10^{8}\right.$ copies $\left./ \mathrm{mL}\right)$, and elevated aminotransferases. There are two hypotheses explaining the reactivation of $\mathrm{HBV}$ replication. Precore (Pre-c) mutations abrogate HBeAg synthesis by creating a translational stop codon, while basal core promoter (BCP) mutations reduce HBeAg expression by transcriptional mechanisms [20-22]. Thus, anti-HBe in IT patients is not specific for the mutant virus. This does not seem to be true in HBeAg seroconversion sense. Therefore, no patient in $\mathrm{HBeAg}$-negative chronic hepatitis $\mathrm{B}$ was taken into $\mathrm{HBeAg}$ seroconversion group.

We found isolated DC from ISC patients exhibited similar expression of surface markers, alloreactive $\mathrm{T}$ cell stimulation, and IL-12 secretion as control DC, corresponding to previous findings [23].

HBV genotypes were previously shown to have distinct geographic and ethnic distribution, with genotypes $\mathrm{B}$ and C prevailing in Southeast Asia [24], and our present study further confirmed this finding; all the patients were of genotype $\mathrm{B}$ or genotype $\mathrm{C}$. Previous studies have shown that HBV genotypes influence disease severity and longterm clinical outcomes of HBV infection [25]. Compared to genotype $\mathrm{B}$ patients, genotype $\mathrm{C}$ patients have late or absent
HBeAg seroconversion after multiple hepatitis flares that accelerate the progression of chronic hepatitis $[24,26]$. Most previous studies indicated that patients with $\mathrm{HBV}$ genotype $\mathrm{C}$ infection have a higher risk of cirrhosis and HCC than those with genotype B infection [27-29]. The impact of viral load on the risk of HCC was assessed in a population-based prospective cohort of untreated CHB Taiwanese patients (REVEALHBV study) [30]. We found that the HBV DNA level of genotype $\mathrm{C}$ was higher than genotype $\mathrm{B}$. The HBV DNA could influence the expression of dendritic cells concentration. But these differences need to be more strictly reconfirmed by a larger number of cases.

In conclusion, the present study demonstrates that DC shows stronger function after $\mathrm{HBeAg}$ seroconversion. The change of the function of DC may play an important role in the difference of immune response and replication of $\mathrm{HBV}$ between IT patients and ISC patients. We planned to pulse DC cells with $\mathrm{HBeAg}$ or $\mathrm{HBcAg}$ to enhance the functions of $\mathrm{DC}$, especially the immune response to $\mathrm{HBeAg}$ in further study.

\section{Conflict of Interests}

The authors declare that there is no conflict of interests regarding the publication of this paper.

\section{References}

[1] F. S. Wang, "Current status and prospects of studies on human genetic alleles associated with hepatitis B virus infection," World Journal of Gastroenterology, vol. 9, no. 4, pp. 641-644, 2003.

[2] W. M. Lee, "Hepatitis B virus infection," The New England Journal of Medicine, vol. 337, no. 24, pp. 1733-1745, 1997.

[3] J. H. Kao and D. S. Chen, "Global control of hepatitis B virus infection," The Lancet Infectious Diseases, vol. 2, no. 7, pp. 395403, 2002.

[4] J. H. Hoofnagle and A. M. di Bisceglie, "The treatment of chronic viral hepatitis," The New England Journal of Medicine, vol. 336 , no. 5 , p. $347,1997$.

[5] A. S. F. Lok and B. J. McMahon, "Chronic hepatitis B," Hepatology, vol. 45, no. 2, pp. 507-539, 2007.

[6] H. J. Yim and A. S.-F. Lok, "Natural history of chronic hepatitis B virus infection: what we knew in 1981 and what we know in 2005," Hepatology, vol. 43, no. 2, pp. S173-S181, 2006.

[7] R. G. van der Molen, D. Sprengers, R. S. Binda et al., "Functional impairment of myeloid and plasmacytoid dendritic cells of patients with chronic hepatitis B," Hepatology, vol. 40, no. 3, pp. 738-746, 2004.

[8] X.-Z. Duan, H. Zhuang, M. Wang, H.-W. Li, J.-C. Liu, and F.-S. Wang, "Decreased numbers and impaired function of circulating dendritic cell subsets in patients with chronic hepatitis B infection (R2)," Journal of Gastroenterology and Hepatology (Australia), vol. 20, no. 2, pp. 234-242, 2005.

[9] N. Romani, S. Gruner, D. Brang et al., "Proliferating dendritic cell progenitors in human blood," Journal of Experimental Medicine, vol. 180, no. 1, pp. 83-93, 1994.

[10] W. C. Van Voorhis, L. S. Hair, R. M. Steinman, and G. Kaplan, "Human dendritic cells. Enrichment and characterization from peripheral blood," The Journal of Experimental Medicine, vol. 155 , no. 4 , pp. 1172-1187, 1982. 
[11] A. Bertoletti, M. Maini, and R. Williams, "Role of hepatitis B virus specific cytotoxic T cells in liver damage and viral control," Antiviral Research, vol. 60, no. 2, pp. 61-66, 2003.

[12] D. Sprengers, R. G. V. D. Molen, J. G. Kusters et al., "Analysis of intrahepatic HBV-specific cytotoxic T-cells during and after acute HBV infection in humans," Journal of Hepatology, vol. 45, no. 2, pp. 182-189, 2006.

[13] J. J. Chang, F. Wightman, A. Bartholomeusz et al., "Reduced hepatitis $\mathrm{B}$ virus (HBV)-specific $\mathrm{CD}^{+}{ }^{+} \mathrm{T}$-cell responses in human immunodeficiency virus type 1-HBV-coinfected individuals receiving HBV-active antiretroviral therapy," Journal of Virology, vol. 79, no. 5, pp. 3038-3051, 2005.

[14] R. Thomas and P. E. Lipsky, "Dendritic cells: origin and differentiation," Stem Cells, vol. 14, no. 2, pp. 196-206, 1996.

[15] R. M. Steinman, "The dendritic cell system and its role in immunogenicity," Annual Review of Immunology, vol. 9, pp. 271296, 1991.

[16] B. Dubois, B. Vanbervliet, J. Fayette et al., "Dendritic cells enhance growth and differentiation of CD40-activated B lymphocytes," Journal of Experimental Medicine, vol. 185, no. 5, pp. 941-951, 1997.

[17] S. Beckebaum, V. R. Cicinnati, X. Zhang et al., "Hepatitis B virus-induced defect of monocyte-derived dendritic cells leads to impaired $\mathrm{T}$ helper type 1 response in vitro: mechanisms for viral immune escape," Immunology, vol. 109, no. 4, pp. 487-495, 2003.

[18] W. Stephan, A. M. Prince, and B. Brotman, "Modulation of hepatitis B infection by intravenous application of an immunoglobulin preparation that contains antibodies to hepatitis $\mathrm{B}$ e and core antigens but not to hepatitis B surface antigen," Journal of Virology, vol. 51, no. 2, pp. 420-424, 1984.

[19] S.-Q. Xiong, B.-L. Lin, X. Gao, H. Tang, and C.-Y. Wu, "IL-12 promotes $\mathrm{HBV}$-specific central memory $\mathrm{CD}^{+} \mathrm{T}$ cell responses by PBMCs from chronic hepatitis B virus carriers," International Immunopharmacology, vol. 7, no. 5, pp. 578-587, 2007.

[20] M. L. Funk, D. M. Rosenberg, and A. S. F. Lok, "Worldwide epidemiology of $\mathrm{HBeAg}$-negative chronic hepatitis B and associated precore and core promoter variants," Journal of Viral Hepatitis, vol. 9, no. 1, pp. 52-61, 2002.

[21] A. Laras, J. Koskinas, K. Avgidis, and S. J. Hadziyannis, "Incidence and clinical significance of hepatitis B virus precore gene translation initiation mutations in e antigen-negative patient," Journal of Viral Hepatitis, vol. 5, no. 4, pp. 241-248, 1998.

[22] C.-L. Lin, L.-Y. Liao, C.-J. Liu et al., "Hepatitis B genotypes and precore/basal core promoter mutants in HBeAg-negative chronic hepatitis B," Journal of Gastroenterology, vol. 37, no. 4, pp. 283-287, 2002.

[23] S. Tavakoli, I. Mederacke, S. Herzog-Hauff et al., "Peripheral blood dendritic cells are phenotypically and functionally intact in chronic hepatitis B virus (HBV) infection," Clinical and Experimental Immunology, vol. 151, no. 1, pp. 61-70, 2008.

[24] J.-H. Kao, P.-J. Chen, M.-Y. Lai, and D.-S. Chen, "Hepatitis B virus genotypes and spontaneous hepatitis $\mathrm{B}$ e antigen seroconversion in Taiwanese hepatitis B carriers," Journal of Medical Virology, vol. 72, no. 3, pp. 363-369, 2004.

[25] T. Maeshiro, S. Arakaki, T. Watanabe et al., "Different natural courses of chronic hepatitis B with genotypes B and C after the fourth decade of life," World Journal of Gastroenterology, vol. 13, no. 34, pp. 4560-4565, 2007.

[26] J.-H. Kao, P.-J. Chen, M.-Y. Lai, and D.-S. Chen, "Genotypes and clinical phenotypes of hepatitis B virus in patients with chronic hepatitis B virus infection," Journal of Clinical Microbiology, vol. 40, no. 4, pp. 1207-1209, 2002.

[27] C. J. Liu and J. H. Kao, "Global perspective on the natural history of chronic hepatitis B: role of hepatitis B virus genotypes A to J," Seminars in Liver Disease, vol. 33, no. 2, pp. 97-102, 2013.

[28] J.-H. Kao, P.-J. Chen, M.-Y. Lai, and D.-S. Chen, "Hepatitis $\mathrm{B}$ genotypes correlate with clinical outcomes in patients with chronic hepatitis B," Gastroenterology, vol. 118, no. 3, pp. 554$559,2000$.

[29] H.-I. Yang, S.-H. Yeh, P.-J. Chen et al., "Associations between hepatitis $\mathrm{B}$ virus genotype and mutants and the risk of hepatocellular carcinoma," Journal of the National Cancer Institute, vol. 100, no. 16, pp. 1134-1143, 2008.

[30] C.-J. Chen and H.-I. Yang, "Natural history of chronic hepatitis B REVEALed," Journal of Gastroenterology and Hepatology (Australia), vol. 26, no. 4, pp. 628-638, 2011. 


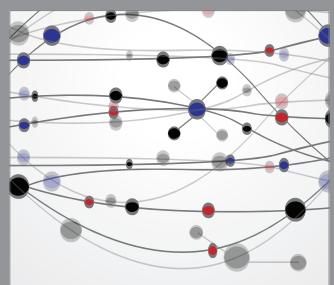

The Scientific World Journal
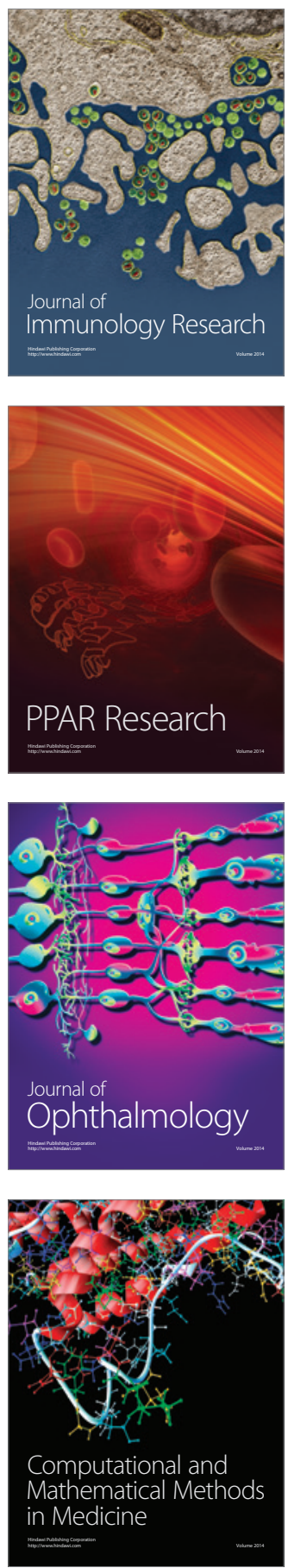

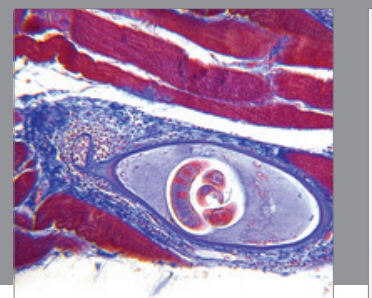

Gastroenterology

Research and Practice
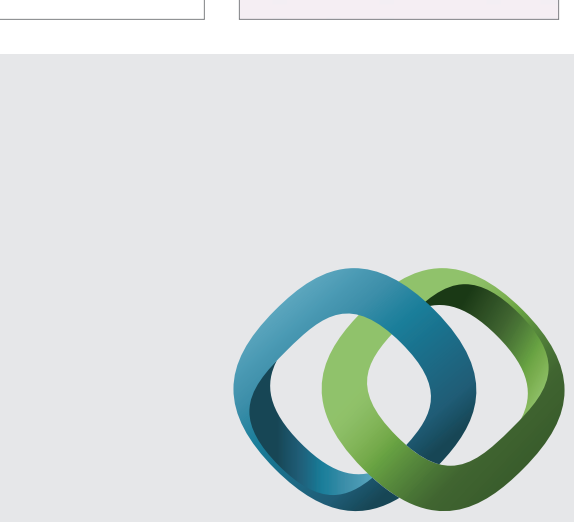

\section{Hindawi}

Submit your manuscripts at

http://www.hindawi.com
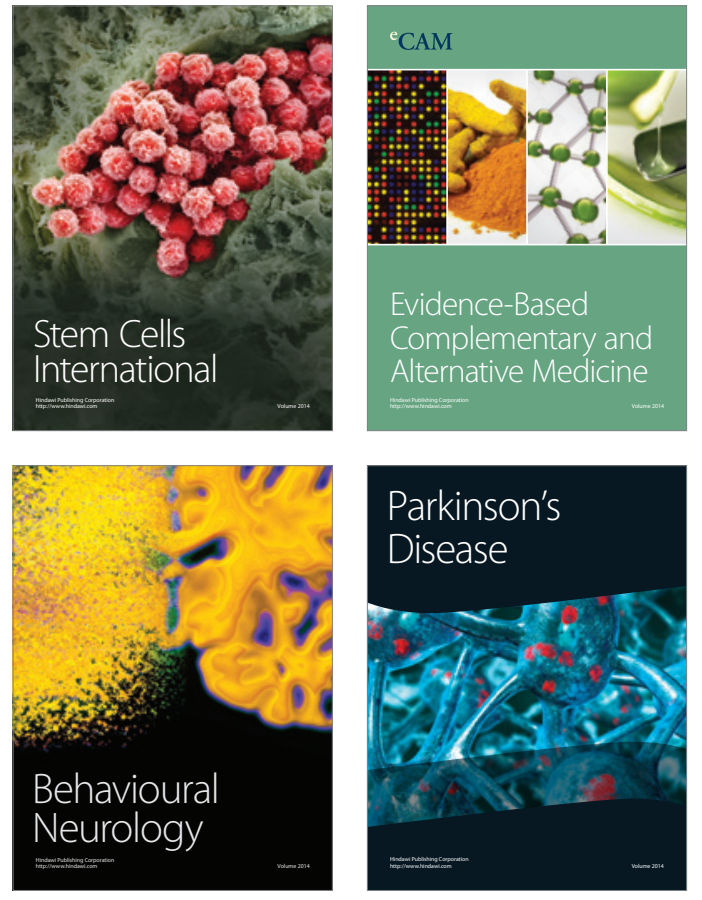
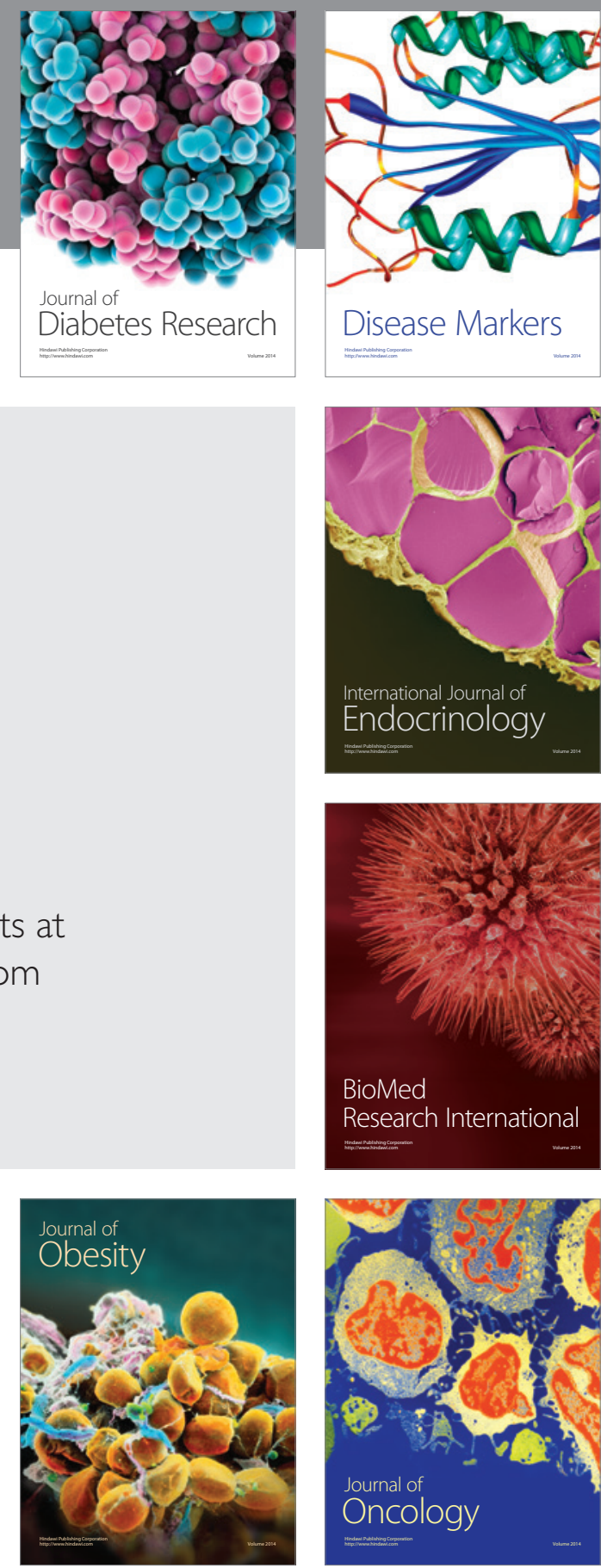

Disease Markers
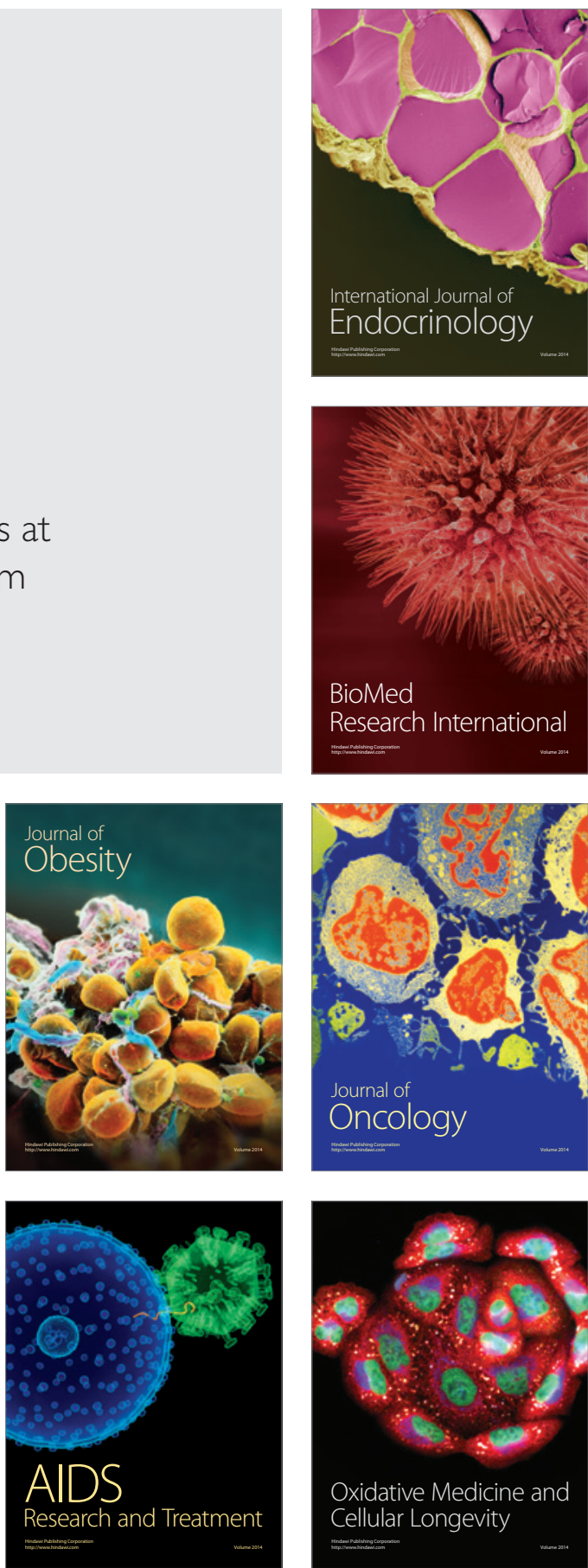